\title{
ARISTOCRACY AND POLITICS
}

\author{
Further Discussion of Mr. Alleyne Ireland's Article \\ Prescott F. Hall
}

M R. A L LE Y NE IRELAND'S article "A Biological View of Politics," in the December number of the JourNal, states a view with which many serious students are in sympathy, but which few have the courage to state. I say "courage" because the opposite view is so universal in popular discussion that it seems to be crying in the wilderness to preach against it.

The widespread and fatuous belief in universal suffrage and in what Goncourt called the "barbarism of number" is largely due, I think, to the increasing prevalence of a new psychological type. For lack of a better term I have coined the word "expansile" to designate it. Just as we have "motiles," "audiles" and "visuels," depending upon which sense is most active, so we have "expansiles," whose characteristic is that they are the victims of any idea which is broader or more inclusive quantitatively than some other. What bodily variation is correlated with this is not clear; but it may be a symbol, in the psycho-analytic sense, of claustrophobia, and may signify a reaction from the increasing urban life. The expansile tendency is especially marked in the desire for "equality" of any kind, this being a species of inclusiveness. In fact, in some persons, the lust for equality becomes a form of paranoia. Thus, if the discussion is of suffrage, everyone should have a vote; if of wages, everyone should have an equal wage; if of education, everyone should have an equal opportunity. The idea of proportional opportunity, by which those most gifted should have the best chance, is obnoxious to the expansile. The kind of thing often expressed in the phrase "brotherhood of man" implies the maximum of expansion and equality; although logically altruism is perfectly consistent with inequality.
The most disastrous example of false reasoning under the influence of the expansile tendency was provided by the French Revolution. It is well known that certain Masonic societies had a good deal to do with this event, notably the Grand Orient of France, and the Philathètes of Paris organized by Cagliostro. The false reasoning consisted in assuming that certain principles of equality, which had worked very well among the picked and chosen members of the lodges, could be extended at' a stroke to the whole population of France. The writers of our Declaration of Independence and Constitution, being $\mathrm{Ma}$ sons, adopted the language of these principles when this country started on its separate existence. Fortunately, the population of the United States at that time consisted of picked specimens of the Nordic race, selected by the perils of voyaging hither and of exploiting a new country. These people had sense enough to entrust the management of their affairs to the most capable among them; so that, for some sixty or seventy years the government, although democratic in form, was aristocratic in fact. At the present time this is no longer true. Respect for intelligence and ability have so far disappeared that it is almost impossible for a strong and able man of independent views to be elected to high office. To get into office, a man must now play the demagogue.

The result is a lowering both of ideals and of execution. The popular opinion of the masses must be consulted at every step. Amiel says: "The stupidity of the Demos is equalled only by its presumption. It is an adolescent who has power but cannot attain reason... Democracy rests on the legal fiction that the majority has not only power but reason, that it possesses wisdom as well as legal rights.. The masses will always be below the average, . . . and 
democracy will end up in the absurdity of leaving the decision of the most important questions to those most incapable. This is the penalty for its abstract principle of equality

which ignores the inequality of valor, or merit, of experience, in other words, of individual effort."

Many champions of the view that intelligence and ability should have no more than their numerical proportion of power in government, in other words, those who believe in government by "counting noses," admit more or less of Amiel's indictment. But they contend that, although democracy in Plato's words is the best form of bad government, it is essential to the education of the people. These persons forget that psychology has shown that the larger part of education consists in imitation and emulation. If the thing before the eyes of the next generation is bad, that is the thing it will imitate and emulate. When a jailbird is elected to high public office, what is the influence on the young politicians and voters? For, as Mr. Ireland points out, if education is not transmitted by heredity; if only the psychic environment is handed on in the form of institutions, books and records, the process of information has to be done over in every generation, and if at any time the institutions have changed for the worse, the educational facilities are lowered also.

The more intelligent a community, the more it tends to recognize and venerate ability and merit. In an intelligent electorate, the aristo $i$ always have more than their numerical quantum of power, even under democratic forms. Hence there democracy works relatively well. But elsewhere, and especially under all forms of "pure democracy," this is not so. The matter is further complicated by the demand for socialism. As Emile Faguet points out, democracy, having for its principle equality of political rights, is the greatest breeder of aristocrats; for there is complete freedom and inequality as regards natural conditions. As soon as this is perceived, socialism demands equality also in these natural conditions; hence socialism is as directly opposed to democracy as aristocracy is, but with the difference that it seeks to level everything instead of favoring the best.

$\mathrm{Mr}$. Ireland seems to me entirely right in holding with Nietzsche, Schopenhauer, Renan, James and many historians, that great men lead their age, instead of being the result of their environment; and no doubt he would agree that progress is to be measured by the achievements of the greatest rather than by the condition of the average. As a matter of fact, as Lecky and Mallock have shown, pure democracy is an impossibility, except in a relatively small area where the people are intelligent and homogeneous in character if not in race. Elsewhere, it is simply a question of what kind of oligarchy shall govern; for there will be an oligarchy either of aristocrats or of demagogues and bosses. By aristocrats I mean those of special intelligence and ability. These qualities, as $\mathrm{Mr}$. Ireland shows, are in general hereditary; and in the early days when the Nordic race overran Europe, it rightfully became the aristocracy of Europe by virtue of the possession of these qualities. At a later period, for various reasons, the identity of privilege and ability no longer held good in many cases; so that I am not now contending for special power based solely on ancestry.

But even where the better sort of men have the leadership, they are often subject to the temptation to weaken it for the benefit of a temporary advantage. Nearly every extension of the suffrage has been the result of a bargain in which some party in power has traded the public good for the adherence of some faction hitherto denied the ballot, and usually in the name of progress and reform. Ludovici has pointed out the deterioration in the British House of Lords through the successive creations of life peers, mostly made to tide over some political crisis; and that the addition of men unused to legislation, even though able in other lines, weakened the average capacity of the House. The same thing can be said of the broadening of the electorate itself. And yet the recent abolition of plural voting in Belgium has been hailed as a step on the 
road to the New Jerusalem! In this country, so far as I am aware, there have been only three cases where the suffrage has been changed from a broader to a narrower basis. In early Massachusetts, it was limited by a vote of all the colonists to church members and property owners; in New Jersey, woman suffrage was abolished early in the nineteenth century; and in Rhode Island, the property-owning qualification of $\$ 75$ was recently raised to $\$ 300$.

In my opinion, we never shall have good government until the suffrage is limited to those having a certain education, or paying a certain tax; perhaps also allowing those to vote who are willing to pay a fee for the privilege. We never shall have good financial management in cities where, as in Boston, 118,000 non-taxpayers spend the money of 18,000 tax-payers. For, taking things on the average, as we always have to do in sociological questions, the liability to a tax implies a certain measure of success and ability. That is why the Bolshevist, who is a mentally and nervously irritable person, filled with hate in the form of envy, is so against property as an institution.

Limitation of the suffrage may seem impossible of accomplishment in these times, when we are seeking the smallest possible political unit, even as we try to split up the atoms of physical matter; and yet, if everyone would speak out who desires it, the achievement might not be so remote. Perhaps the most pregnant saying of Goethe, which embodied a generalization from his wide study of biology and other sciences, was that anything to succeed must have "Beschraenkung"-limitation. Goethe was not what I have called an expansile. $\mathrm{He}$ would doubtless have recognized that the chief danger of the American people today is the tendency to follow out logically abstract ideals without reference to the concrete situation. This, as LeBon has shown, is a tendency indigenous to the Latin but not to the Nordic spirit. We are developing it partly through the dilution of our national character by immigration, and partly by hearkening to the catchwords of expansile leaders and those who wallow in humanitarian platitudes.

Therefore we should all be grateful to Mr. Ireland for stating the case so clearly, and for his testimony to the value of aristocracy, based on his long and thorough study of various experiments in government.

\section{Plant Breeder's Envelope}

The plant breeder's envelope, described in the following paragraph, worked admirably on tender succulent flax plants and ought to be of use for other delicate plants. It has the advantages of being light in weight, insect proof, moisture proof, and of being readily adapted and used. (Fig. 6.)

A piece of oiled paper is folded or doubled the desired width, with an additional inch or two which is to be left unstitched to facilitate opening the envelope. A sewing machine is used to stitch off as many envelopes as the length of the folded sheet will permit. The envelopes are cut apart with scissors and slit up through the middle of the unstitched portion at the base. At the crotch of this slit a hole is cut of sufficient size for the plant stem to fit snugly when enclosed. One half, sec- tion $B$, of the unstitched portion is folded lengthwise towards the top of the envelope. The other half, section $A$, is folded on a forty-five degree slant over the first half. Points $c, d$, and e coincide, and at this corner where the folded parts overlap a snap fastener such as is used on women's dresses is used to fasten the envelope base together. The plant breeder's envelope is now in the same position as when enclosing an emasculated flower on the stem of a plant. The unstitched portion at the envelope base must be one-half, or less than one-half, the width of the envelope in length so that, when folded, there will be no unstitched portion above the fold. RoBert L. DAVIS, Scientific Assistant, Fiber Investigations, $U . S$. Department of Agriculture, ITashington, $D . C$. 